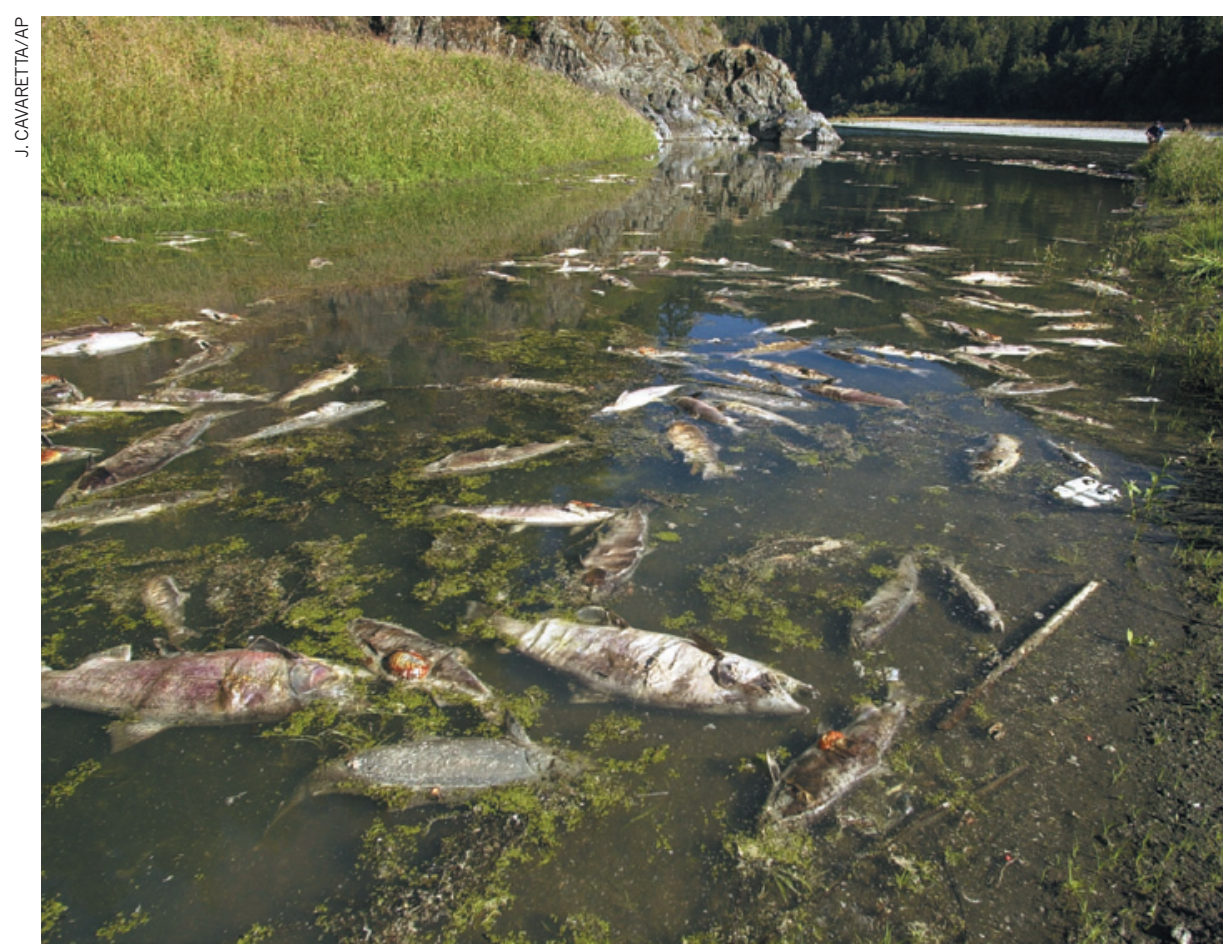

Salmon deaths in the Klamath River have prompted legislation to remove dams and restore water flow.

\title{
POLICY
}

\section{US integrity effort hits troubled water}

\section{Allegations by integrity officer who lost his job are a setback for plan to quash political interference in science.}

\section{BY EUGENIE SAMUEL REICH}

$\mathrm{W}$ hen US President Barack Obama announced a government-wide effort to protect federal science from political interference, the US Department of the Interior (DOI) took an early lead. In 2011, it became the first agency to finalize a new policy on scientific integrity and it has hired ten scientific-integrity officers to work with staff in its various bureaus. But the DOI may also be the first to run into a problem with the way the policies are implemented, as one of those officers claims to have been fired for upholding the guidelines.

"I thought I was doing the job I was hired to do and was doing the right thing. I was stifled," says Paul Houser, a hydrologist at George Mason University in Fairfax, Virginia, who was appointed as scientific-integrity officer for the DOI's Bureau of Reclamation in April 2011. Houser was fired on 10 February and filed a complaint under the DOI's scientific-integrity policy two weeks later.

Houser alleges that he lost his job because he raised concerns with the DOI about the way it had represented the science behind a plan to remove four hydroelectric dams from a stretch of the Klamath River that straddles the California-Oregon border. DOI spokeswoman Kate Kelly declined to say why Houser had been fired. But watchdog groups say that Houser's complaint underscores the need for protections for those tasked with enforcing the new policies.

"There are things the president has to lead on and whistle-blower protection is one of them," says Francesca Grifo, director of the Union of Concerned Scientists' scientificintegrity programme in Washington DC.

Houser says that his concerns conflicted with the DOI's desire to build a strong public case for removing the dams. Environmental groups support the removal because the dams reduce water flow in the river and have been blamed for large numbers of salmon deaths.
Secretary of the Interior Kenneth Salazar was planning to decide whether the dams should be removed by 31 March, but legislation authorizing removal has stalled in the US Congress.

Houser says that he was asked by a press officer to check some material that the DOI planned to make public about the probable environmental impact of the dams' removal. But the material painted an overly rosy picture of the benefit, Houser says. For example, in a summary document, the DOI said that studies had shown that the annual production of Chinook salmon (Oncorhynchus tshawytscha) would rise by $83 \%$ a year after the dams were removed. However, it did not include any of the uncertainties about how the population would respond that an expert panel commissioned by the DOI had listed. In the final version of the summary - which is now on a government website - the number was changed to $81.4 \%$. "That number expresses an accuracy that's ludicrous," says Houser. The figure comes from an unpublished computermodelling study and had an uncertainty range of $-59.9 \%$ to $881.4 \%$, which was not reported in the summary.

Houser says that last September, his supervisor, deputy commissioner for external and intergovernmental affairs Kira Finkler, chided him for documenting his concerns. He says Finkler told him that "the secretary wants to remove those dams". Finkler did not respond to questions from Nature about the situation, but the scientific-integrity officer who is overseeing implementation of the department's policy, Ralph Morgenweck, confirms that Houser's complaint is being investigated.

Kelly says that the DOI is looking forward to the outcome of the investigation. "We believe all actions will be proven to be fully justified," she says, adding that the studies the agency is using about the impact of the dam removal are available on the Internet for anyone to see and review. However, members of the expert panel contacted by Nature have said that they, too, felt that the materials flagged by Houser played down the uncertainties in scientific predictions.

The 30 March deadline for US sciencerelated agencies to finalize their integrity policies has now passed, but cases such as Houser's could set the tone for how well the effort takes root, says Grifo. "These early examples are incredibly important."

Both Grifo and Jeff Ruch, executive director of the watchdog group Public Employees for Environmental Responsibility in Washington DC, believe that an absence of whistle-blower protections is likely to make the policies less effective. And for Houser, the departmental hierarchy may not have helped: the scientificintegrity officers report to the heads of the bureaus they work with, which seems to leave the officers vulnerable and could weaken their ability to uphold policies. Morgenweck says that the DOI may reconsider the reporting line when it next revises its policy. 